\title{
P300 and decision-making in neuromarketing
}

\author{
Aida Azlina Mansor ${ }^{1 *}$, Salmi Mohd Isa ${ }^{2}$ and Syaharudin Shah Mohd Noor ${ }^{3}$ \\ ${ }^{1}$ Faculty of Business and Management, Universiti Teknologi MARA, Selangor, Malaysia. \\ ${ }^{2}$ Graduate School of Business, Universiti Sains Malaysia, Penang, Malaysia. \\ ${ }^{3}$ School of Housing, Building and Planning, Universiti Sains Malaysia, Penang, Malaysia. \\ * Correspondence: aidaazlina@uitm.edu.my; Tel.: +603-3258 5030
}

Received: 30 June 2021; Accepted: 5 August 2021; Published: 4 September 2021

Edited by: King-Hwa Ling (Universiti Putra Malaysia, Malaysia)

Reviewed by: Muhamad Kamal Mohammed Amin (Universiti Teknologi Malaysia, Malaysia);

Chiemelie Benneth Iloka (University of Science and Technology, Nigeria)

https://doi.org/10.31117/neuroscirn.v4i3.83

\begin{abstract}
Neuromarketing provides insights into consumers' decision-making that traditional marketing test methods cannot offer. The foundation in the process of decision-making is P300. Thus, the P300 wave is a potential Event-Related Component (ERP) used to measure consumers' decision-making process. The P300 wave represents a positive transition in human event-related potential. Therefore, the P300 is determined by measuring the amplitude and latency of the consumers. A higher P300 amplitude indicates greater confidence in the decision-making process, while a longer P300 latency indicates lower attentiveness. Thus, P300 in neuroscience, which investigates customers' responses in-depth, cannot be accomplished by typical marketing methods. For many years, P300 components such as attitudes, preferences, and informationbased decision-making have been examined extensively in marketing-related research. However, a review of an ERP in neuromarketing method is fewer reported. This mini-review describes some analysis on P300 and decision-making by several researchers.
\end{abstract}

Keywords: Neuromarketing; P300 amplitude; marketing; decision-making;

C2021 by the Mansor et al. for use and distribution according to the Creative Commons Attribution (CC BY-NC 4.0) license (https://creativecommons.org/licenses/by-nc/4.0/), which permits unrestricted non-commercial use, distribution, and reproduction in any medium, provided the original author and source are credited.

\subsection{INTRODUCTION}

Neuromarketing is a study area that combines neuroscience principles and conventional marketing research ideas to assess how customers' decisions process responds to marketing stimuli. Neuromarketing employs cognitive behavioural activities to understand consumers' subconscious mind, explain consumers' preferences, motivations, and expectations, and predict consumers' behaviour (Bercea, 2011; Colaferro \& Crescitelli, 2014; Dapkevičius \& Melnikas, 2009; Fugate, 2007). To achieve these objectives, neuromarketers use a wide range of neuromarketing techniques and technology to measure neurological brain activity. For example, neuromarketing tools such as, Functional Magnetic Resonance Imaging (fMRI),
Electroencephalography (EEG), and eye-tracking are capable of analysing consumers' decision-making process in detail (Roth, 2014; Zurawicki, 2010). This is because neuromarketing is very significant for quantifying and recording consumer decision-making, cognitive and emotional processes towards marketing campaigns (Alsharif et al., 2021). These neuromarketing tools can help researchers and marketers develop effective approaches and provide innovative and efficient services to consumers. Thus, the results gathered from neuromarketing tools should generously provide insights into consumers' decision-making that traditional marketing test methods cannot offer. Neuromarketing can reveal what is happening in the brain in response to some advertising stimuli and the 
application of neuromarketing can reveal which strategy leads to the buying decision (Zito et al., 2021). This innovative idea offers new perspectives and effective tools in marketing research, particularly in consumer analysis (Mansor \& Isa, 2020).

Detailed research of a neuromarketing method is fewer reported, such as Event Related Potential (ERP). As a result, this paper provides a review format for one of the neuromarketing components, ERP. ERP is a specific technique that uses time-locked activity, i.e. brainwave responses triggered by stimuli to help capture sensory and cognitive-related neural activity, which is strongly associated with the decision-making process. These attributes of the ERP can be used as dependent variables in consumers' decision-making processes, according to Johnson and Donchin (1982). The P300, also called the "P3" wave, is an ERP component foundation in the process of decision making. P300 correlated to the decision-making process when subjects are required to decide stimuli (Pirtošek et al., 2009; Wang et al., 2015).

\subsection{P300 AND DECISION MAKING}

The event-related potential (ERP) is used to record a brain signal as it is a non-invasive and risk-free method during auditory and visual stimulus (Key et al., 2005). According to Begum \& Reza (2021), ERP responses are divided into 2; early wave (first 100 ms after stimulation) and late wave (after $100 \mathrm{~ms}$ after stimulus) can be recorded during ERP study. To measure consumers' decision-making, P300 is the main component of brainwaves, a basis in decision-making (Luck, 2005), and the catalyst for the brain to process incoming information. For many years, P300 components such as attitudes, preferences, and information-based decision-making have been studied in marketing-related fields (Lin et al., 2018).

The P300 component is characterised by its amplitude (size) and latency (timing). Amplitude $(\mu \mathrm{V})$ is defined as the voltage difference between the component peak, and the pre-stimulus baseline, whereas latency (ms) is defined as the time from stimulus onset (Mayaud et al., 2013). In the present study, P300 components were collected from participants who responded to stimuli on a computer screen. Respondents' brainwaves were subsequently recorded with EEG (Berry, 2011). P300 occurred around 300 milliseconds and 600 milliseconds after respondents had produced a simple task (Bledowski, 2004; Harris et al., 2018; Horlings et al., 2008; Jongsma et al., 2013; Pirtošek et al., 2009; Powers et al., 2015). The component P300 was calculated by assessing amplitude and latency (Sowndhararajan et al., 2018).

The higher P300 amplitude was positively linked with confidence in the decision-making process (Pirtošek et al., 2009). In fact, Luck (2005) argued in favour of this position because when respondents put more effort into a task, the amplitude of P300 was higher. Consequently, higher amplitudes of P300 components reflected higher awareness. Using EEG methods, researchers can distinguish between cause and effect, marketing stimuli, and the associated cognitive response (Lin et al., 2018). In the latest ten years, numerous empirical studies about decision-making using P300. Table 1 summarises studies on amplitude and latency components of P300 and decision-making.

\subsection{DISCUSSION}

Table 1 shows that during the decision-making process, the outcomes of the study focused around P300 amplitude and latency. P300 is referred to as a valuable tool for cognitive function measurement. This is because knowledge about P300 will be essential to understand its cognition better. Each of the P300 components discussed in this review has distinguishable and important roles in cognitive processes. The researchers also proposed P300 study should include larger groups of participants.

The focus or target of the experiment served as standard and target stimuli. Rosenfeld et al (2005) found that the P300 amplitude was greater than nontargets. Another study also found a significant increase in the latency and P300 amplitude for the target condition of all analysed electrodes compared to the non-target condition. Similarly, Pileliene and Grigaliunaite (2017) found a larger P300 amplitude for the target (celebrity spokesperson) compared to the non-target (non-celebrity spokesperson). This difference suggests that the amplitude of $\mathrm{P} 300$ reflects the attention given to updating memory content (Saliasi et al., 2013).

Luck (2005) opined that the P300 amplitude is larger when subjects make a significant effort in a task; however, the P300 amplitude is smaller if the subject is unsure whether a given stimulus was a target or a nontarget. Confidence in the decision was positively correlated with the P300 amplitude, which indicates that greater confidence in the decision-making process results in a higher P300 amplitude (Pirtošek et al., 2009). Conversely, Samsuri et al. (2018) found higher P300 component amplitudes at most brain sites in the target 
Table 1: Studies on amplitude and latency of P300

\begin{tabular}{|c|c|c|}
\hline Author & Objective & Results \\
\hline Ma et al. (2008) & $\begin{array}{l}\text { To decide the suitability of extending the brand } \\
\text { in stimulus } 1 \text { to the product category in stimulus } \\
2 \text { during a S1-S2 paradigm. }\end{array}$ & $\begin{array}{l}\text { The higher the perceived similarity of their } \\
\text { attributes, the larger the amplitude of the } \\
\text { P300. }\end{array}$ \\
\hline $\begin{array}{l}\text { Porbadnigk et al. } \\
(\underline{2010})\end{array}$ & $\begin{array}{l}\text { To investigate the use of Event Related } \\
\text { Potentials (ERPs) as a quantitative measure for } \\
\text { quality assessment of disturbed audio signals. }\end{array}$ & $\begin{array}{l}\text { The harder it is to detect noise in a stimulus, } \\
\text { the higher the latency and the lower the } \\
\text { amplitude of the P300 component. }\end{array}$ \\
\hline Machado et al. (2014) & $\begin{array}{l}\text { To investigate possible correlations among the } \\
\text { source(s) involved in the generation of the P300 } \\
\text { and their possible neurocognitive function. }\end{array}$ & $\begin{array}{l}\text { Greater amplitude was easily detected in this } \\
\text { region for the target condition. }\end{array}$ \\
\hline Wang et al. (2015) & $\begin{array}{l}\text { To contrast the neural temporal features of the } \\
\text { early stage of decision-making in the context of } \\
\text { risk and ambiguity. }\end{array}$ & $\begin{array}{l}\text { The P300 amplitude elicited in risky conditions } \\
\text { was significantly larger than the amplitude in } \\
\text { ambiguous condition. }\end{array}$ \\
\hline Teixeira et al. (2015) & $\begin{array}{l}\text { To evaluate the electrophysiological and } \\
\text { behavioural changes occurring in the P300 after } \\
\text { consuming modafinil ( } 200 \mathrm{mg} \text { ) and bromazepam } \\
(6 \mathrm{mg}) \text { in healthy subjects. }\end{array}$ & $\begin{array}{l}\text { A significant increase in the P300 latency and } \\
\text { amplitude for the target condition compared } \\
\text { to the non-target condition for all analysed } \\
\text { electrodes. } \\
\text { No significant difference was found for group } \\
\text { or moment. }\end{array}$ \\
\hline Fabre et al. (2015) & $\begin{array}{l}\text { How participants playing the ultimatum game as } \\
\text { responders modulate their decisions according } \\
\text { to the proposers' stereotypical identity. }\end{array}$ & $\begin{array}{l}\text { Greater P } 300 \text { amplitudes } \\
\text { were found in response to both fair and unfair } \\
\text { offers. }\end{array}$ \\
\hline He et a & $\begin{array}{l}\text { Examined the influence of social distance on } \\
\text { outcome feedback by requiring participants to } \\
\text { make decisions for themselves, their friends, or } \\
\text { strangers }\end{array}$ & $\begin{array}{l}\text { Increased social distance reduced the } \\
\text { feedback-related negativity amplitude in the } \\
\text { early stage of outcome evaluation and reduced } \\
\text { the P300 amplitude in the late stage of } \\
\text { outcome evaluation. }\end{array}$ \\
\hline Sehrig et al. (2019). & $\begin{array}{l}\text { Focused on decision-related versus feedback- } \\
\text { related processes as potential contributors to } \\
\text { decision-making in AUD by examining the } \\
\text { relationship between decision choices and } \\
\text { decision- and feedback-related ERP phenomena } \\
\text { in the balloon analogue risk task (BART). }\end{array}$ & $\begin{array}{l}\text { The decision P3 } 200-400 \text { ms after decision } \\
\text { prompt (balloon) was larger in AUD than in HC, } \\
\text { and decision P3 enhancement on high-risk } \\
\text { trials predicted choices to pump. }\end{array}$ \\
\hline Sun et al. (2020) & $\begin{array}{l}\text { The investigate the outcome of decisions } \\
\text { influences behavioural changes }\end{array}$ & $\begin{array}{l}\text { P300, and late positive potential (LPP) served } \\
\text { as the neural substrates for behavioural } \\
\text { decision }\end{array}$ \\
\hline Li et al. (2020). & $\begin{array}{l}\text { Examining how social distance modulates costly } \\
\text { prosocial behaviours in the gain (i.e., helping } \\
\text { another win a good outcome) and loss contexts } \\
\text { (i.e., helping another avoid a bad outcome). }\end{array}$ & $\begin{array}{l}\text { A larger P3 was observed in response to } \\
\text { prosocial decision-making for friends than for } \\
\text { strangers, while the effect of social distance } \\
\text { did not emerge in P3 under the loss context }\end{array}$ \\
\hline
\end{tabular}

view than in the non-target view. According to Luck (2005), higher P300 component amplitudes occurs because subjects put more effort into a task. Dehaene et al. (1998) and Dehaene et al. (2003) agreed that higher P300 component amplitudes reflect higher awareness. If a task is made more difficult, it could increase the P300 amplitude by encouraging subjects to devote more effort to the task. However, it could also reduce the $\mathrm{P} 300$ amplitude by making subjects unsure of the stimulus category (Luck, 2005).
Longer P300 latency showed less attention (Brookhuiset al., 1983). Reimann and Bechara (2010) argued that a longer latency choice response is associated with the new brands compared to well-known brands. Latency also increases when targets are more difficult to distinguish from non-targets (Linden, 2005). The increase in P300 latency is linked to difficulty processing cognitive information (Cheng \& Hsu, 2011). Moreover, (Emmerson et al., 1989; Johnson et al., 1985; Pelosi et al., 1992; Polich et al., 1983), as cited in Polich (2007), 
found that individual differences in P300 latency are correlated with the speed of mental function so that shorter latencies are linked to superior cognitive performance. Regarding complex decisions, longer latency responses are observed (Lepping et al., 2015). Lin et al. (2018) posited that a bigger amplitude in marketing associated with unfamiliar brands and longer P300 latency indicated less attention. The P300 latency was prolonged when the stimulus was cognitively difficult to process (Cheng \& Hsu, 2011). Thus, the amplitude and latency of the P300 primarily reflected the depth or degree of cognitive stimulus processing (Sowndhararajan et al., 2018). In other words, it was closely linked to the level of attention.

In layman terms, a higher P300 amplitude indicates greater confidence in decision-making, higher awareness, and more effort being put into a task. Meanwhile, longer P300 latency was associated with lower attention and difficulty processing cognitive information. Both variables are associated with how consumers make decisions.

\subsection{CONCLUSIONS}

Due to failure in understanding the consumers' decision-making process, $80 \%$ of all new products are unsuccessful in their first year. This challenge is addressed through neuroscience tools that help uncover hidden information oblivious to traditional marketing methods. With the help of neuroscience, the consumers' decision-making process is made known. Therefore, marketers can use the available information such as P300 from ERP to adjust and improve their marketing strategies appropriately. Researchers have shown interest in using neuroscience technology in marketing research to study consumers' response in detail and close the existing gap. New researchers may help investigate more of the role of P300 in consumer decisions in the presence of multiple writers. Nonetheless, despite its advancement in academia, its implementation in the professional sector remains a big challenge. As a result, more researchers and marketers can be trained in neuromarketing to develop more capable and effective marketing strategies to beat the challenges.

Acknowledgements: The authors would like to acknowledge the Faculty of Business and Management (UiTM), Graduate School of Business (USM), and Skim Latihan Akademik IPTA (SLAI) by Kementerian Pendidikan Tinggi Malaysia for funding and supporting this study.

Author Contributions: All authors contributed to the idea, interpretation, writing and revision of the article.

Conflicts of Interest: The authors declare no conflict of interest.

\section{References}

Albert, N., Merunka, D., \& Valette-Florence, P. (2008). When consumers love their brands: Exploring the concept and its dimensions. Journal of Business Research, 61(10), 1062-1075. https://doi.org/10.1016/i.jbusres.2007.09.014

Alsharif, A. H., Salleh, N. Z. M., Baharun, R., Hashem E, A. R., Mansor, A. A., Ali, J., \& Abbas, A. F. (2021). Neuroimaging techniques in advertising research: main applications, development, and brain regions and processes. Sustainability, 13(11), 6488. https://doi.org/10.3390/su13116488

Begum, T., \& Reza, F. (2021). Auditory cognitive function assessment during pregnancy: an event-related potential and neuropsychological study. Bangladesh Journal of Medical Science, 20(3), 608-617. https://doi.org/10.3329/bjms.v20i3.52803

Bercea, M. D. (2012). Anatomy of methodologies for measuring consumer behavior in neuromarketing research. In Proceedings of the Lupcon Center for Business Research (LCBR) European Marketing Conference. Ebermannstadt, Germany.

Berry, D. R. (2011). Manipulating paradigm and attention via a mindfulness meditation training program improves $P 300$ Based $\mathrm{BCl}$ (Doctoral dissertation, East Tennessee State University).

Bledowski, C., Prvulovic, D., Hoechstetter, K., Scherg, M., Wibral, M., Goebel, R., et al . (2004). Localizing P300 generators in visual target and distractor processing: a combined event-related potential and functional magnetic resonance imaging study. Journal of Neuroscience, 24(42), 9353-9360. https://doi.org/10.1523/JNEUROSCI.1897-04.2004

Brookhuis, K., Mulder, G., Mulder, L., \& Gloerich, A. (1983). The P3 complex as an index of information processing: The effects of response probability. Biological Psychology, 17(4), 277-296. https://doi.org/10.1016/0301-0511(83)90004-2

Cheng, S.Y., \& Hsu, H.T. (2011). Mental fatigue measurement using EEG. Risk Management Trends. https://doi.org/17370

Colaferro, C. A., \& Crescitelli, E. (2014). The contribution of neuromarketing to the study of consumer behavior. Brazilian Business Review, 11(3), 123-143. https://doi.org/10.15728/bbr.2014.11.3.6

Dapkevičius, A., \& Melnikas, B. (2009). Influence of price and quality to customer satisfaction: neuromarketing approach. Mokslas - Lietuvos Ateitis, 1(3), 17-20. https://doi.org/10.3846/144

Dehaene, S., Kerszberg, M. \& Changeux, J.P. (1998) A neuronal model of a global workspace in effortful cognitive tasks. Proceedings of the National Academy of Sciences of the United States of America, 95, 14529-14534. https://doi.org/ 


\subsection{3/pnas.95.24.14529}

Dehaene, S., Sergent, C., \& Changeux, J. P. (2003). A neuronal network model linking subjective reports and objective physiological data during conscious perception. Proceedings of the National Academy of Sciences, 100(14), 8520-8525. https://doi.org/10.1073/pnas.1332574100

Duncan-Johnson, C. C., \& Donchin, E. (1982). The P300 component of the event-related brain potential as an index of information processing. Biological Psychology, 14(1-2), 1-52. https://doi.org/10.1016/0301-0511(82)90016-3

Emmerson, R. Y., Dustman, R. E., Shearer, D. E., \& Turner, C. W. (1989). P3 latency and symbol digit performance correlations in aging. Experimental Aging Research, 15(3), 151-159. https://doi.org/10.1080/03610738908259769

Fabre, E. F., Causse, M., Pesciarelli, F., \& Cacciari, C. (2015). Sex and the money - How gender stereotypes modulate economic decision-making: an ERP study. Neuropsychologia, 75, 221-232. https://doi.org/10.1016/i.neuropsychologia.2015.06.013

Fugate, D. L. (2007). Neuromarketing: a layman's look at neuroscience and its potential application to marketing practice. Journal of Consumer Marketing, 24(7), 385-394. https://doi.org/10.1108/07363760710834807

Harris, J. M., Ciorciari, J., \& Gountas, J. (2018). Consumer neuroscience for marketing researchers. Journal of Consumer Behaviour, 17(3), 239-252. https://doi.org/10.1002/cb.1710

He, Q., Sun, Q., Shi, Z., Zhang, X., \& Hu, F. (2018). Effect of social distance on outcome evaluation in self-other decisionmaking. NeuroReport, 29(17), 1499-1503. https://doi.org/10.1097/wnr.0000000000001141

Horlings, R., Datcu, D., \& Rothkrantz, L. J. (2008). Emotion recognition using brain activity. In Proceedings of the 9th international conference on computer systems and technologies and workshop for PhD students in computing (pp. II-1).

Johnson, R. \& Donchin, E. (1982). Sequential expectancies and decision-making in a changing environment: an electrophysiological approach. Psychophysiology, 19, 183-200. https://doi.org/ 10.1111/i.1469-8986.1982.tb02545.x

Johnson, R., Pfefferbaum, A., \& Kopell, B. S. (1985). P300 and Long-Term Memory: Latency Predicts Recognition Performance. Psychophysiology, 22(5), 497-507. https://doi.org/10.1111/i.1469-8986.1985.tb01639

Jongsma, M. L., van Rijn, C. M., Gerrits, N. J., Eichele, T., Steenbergen, B., Maes, J. H., \& Quian Quiroga, R. (2013). The learning-oddball paradigm: Data of 24 separate individuals illustrate its potential usefulness as a new clinical tool. Clinical Neurophysiology, 124(3), 514-521. https://doi.org/10.1016/i.clinph.2012.09.009

Key, A. P. F., Dove, G. O., \& Maguire, M. J. (2005). Linking brainwaves to the brain: an ERP Primer. Developmental Neuropsychology, 27(2), 183-215. https://doi.org/10.1207/s15326942dn2702 1

Kolar, E. (2014). Neuromarketing and marketing management: contributions of neuroscience for the traditional marketing mix (Bachelor's thesis, University of Twente).

Lepping, R. J., Papa, V. B., \& Martin, L. E. (2015). Cognitive neuroscience perspectives on food decision-making: a brief introduction. Journal of Agricultural \& Food Industrial Organization, 13(1), 5-14. https://doi.org/10.1515/jafio-2015$\underline{0026}$

Li, J., Sun, Y., Li, M., Li, H., Fan, W., \& Zhong, Y. (2020). Social distance modulates prosocial behaviors in the gain and loss contexts: An event-related potential (ERP) study. International Journal of Psychophysiology, 150, 83-91. https://doi.org/10.1016/j.ijpsycho.2020.02.003

Lin, M. H. J., Cross, S. N., Jones, W. J., \& Childers, T. L. (2018). Applying EEG in consumer neuroscience. European Journal of Marketing, 52(1/2), 66-91. https://doi.org/10.1108/ejm-12-2016-0805

Linden, D. E. J. (2005). The P300: where in the brain is it produced and what does it tell us? The Neuroscientist, 11(6), 563576. https://doi.org/10.1177/1073858405280524

Luck, S. J. (2005). An introduction to event related potentials and their neural origins. An introduction to the event related potential technique, 11.

Ma, Q., Wang, X., Shu, L., \& Dai, S. (2008). P300 and categorisation in brand extension. Neuroscience Letters, 431(1), 57-61. https://doi.org/10.1016/i.neulet.2007.11.022

Machado, S., Arias-Carrión, O., Sampaio, I., Bittencourt, J., Velasques, B., Teixeira, S., Nardi, A. E., Piedade, R., \& Ribeiro, P. (2014). Source imaging of P300 visual evoked potentials and cognitive functions in healthy subjects. Clinical EEG and Neuroscience, 45(4), 262-268. https://doi.org/10.1177/1550059413514389

Mansor, A. A., \& Isa, S. M. (2020). Fundamentals of neuromarketing: What is it all about?. Neuroscience Research Notes, 3(4), 22-28. https://doi.org/10.31117/neuroscirn.v3i4.58

Mayaud, L., Congedo, M., van Laghenhove, A., Orlikowski, D., Figère, M., Azabou, E., \& Cheliout-Heraut, F. (2013). A comparison of recording modalities of $\mathrm{P} 300$ event-related potentials (ERP) for brain-computer interface (BCI) paradigm. Neurophysiologie Clinique/Clinical Neurophysiology, 43(4), 217-227. https://doi.org/10.1016/j.neucli.2013.06.002

Pelosi, L., Holly, M., Slade, T., Hayward, M., Barrett, G., \& Blumhardt, L. D. (1992). Event-related potential (ERP) correlates of performance of intelligence tests. Electroencephalography and Clinical Neurophysiology/Evoked Potentials Section, 84(6), 515-520. https://doi.org/10.1016/0168-5597(92)90040-i

Pileliene, L., \& Grigaliunaite, V. (2017). The effect of female celebrity spokesperson in FMCG advertising: neuromarketing approach. Journal of Consumer Marketing, 34(3), 202-213. https://doi.org/10.1108/JCM-02-2016-1723

Pirtošek, Z., Georgiev, De., \& Gregoric-Kramberger, M. (2009). Decision making and the brain: Neurologists' view. 
Interdisciplinary Description of Complex Systems, 7(2), 38-53. http://hrcak.srce.hr/76792

Polich, J. (2007). Updating P300: an integrative theory of P3a and P3b. Clinical neurophysiology, 118(10), 2128-2148. https://doi.org/10.1016/i.clinph.2007.04.019

Polich, J., Howard, L., \& Starr, A. (1983). P300 Latency Correlates with Digit Span. Psychophysiology, 20(6), 665-669. https://doi.org/10.1111/i.1469-8986.1983.tb00936

Porbadnigk, A. K., Antons, J. N., Blankertz, B., Treder, M. S., Schleicher, R., Möller, S., \& Curio, G. (2010). Using ERPs for assessing the (sub) conscious perception of noise. 2010 Annual International Conference of the IEEE Engineering in Medicine and Biology Society, EMBC'10, 2690-2693. https://doi.org/10.1109/IEMBS.2010.5626549

Powers, J., Bieliaieva, K., Wu, S., \& Nam, C. (2015). The human factors and ergonomics of P300-based brain-computer interfaces. Brain Sciences, 5(3), 318-356. https://doi.org/10.3390/brainsci5030318

Reimann, M., \& Bechara, A. (2010). The somatic marker framework as a neurological theory of decision-making: Review, conceptual comparisons, and future neuroeconomics research. Journal of Economic Psychology, 31(5), 767-776. https://doi.org/10.1016/i.joep.2010.03.002

Rosenfeld, J. P., Biroschak, J. R., Kleschen, M. J., \& Smith, K. M. (2005). Subjective and objective probability effects on P300 amplitude revisited. Psychophysiology, 42(3), 356-359. https://doi.org/10.1111/i.1469-8986.2005.00283.x

Roth, V. A. (2014). The potential of neuromarketing as a marketing tool (Bachelor's thesis, University of Twente).

Saliasi, E., Geerligs, L., Lorist, M. M., \& Maurits, N. M. (2013). The relationship between P3 amplitude and working memory performance differs in young and older Adults. PLOS ONE, 8(5), e63701. https://doi.org/10.1371/journal.pone.0063701

Samsuri, N., Reza, F., Begum, T., Yusoff, N., Idris, B., Omar, H., \& Mohd Isa, S. (2018). Application of EEG/ERP and eye tracking in underlying mechanism of visual attention of auto dealer's advertisement -a neuromarketing research. International Journal of Engineering \& Technology, 7(3.22), 5. https://doi.org/10.14419/ijet.v7i3.22.17112

Sehrig, S., Weiss, A., Miller, G. A., \& Rockstroh, B. (2019). Decision-and feedback-related brain potentials reveal risk processing mechanisms in patients with alcohol use disorder. Psychophysiology, 56(12), e13450. https://doi.org/10.1111/psyp.13450

Sowndhararajan, K., Kim, M., Deepa, P., Park, S., \& Kim, S. (2018). Application of the P300 event-related potential in the diagnosis of epilepsy disorder: a review. Scientia Pharmaceutica, 86(2), 10. https://doi.org/10.3390/scipharm86020010

Sun, S., Yu, R., \& Wang, S. (2020). Outcome saliency modulates behavioral decision switching. Scientific reports, 10(1), 1-12. https://doi.org/10.1038/s41598-020-71182-9

Teixeira, S., Pompeu, F. A. M. S., Sandoval-carrillo, A., \& Salas-pacheco, J. (2015). Effects of modafinil and bromazepam on decision-making: a P300 analysis. International Archives of Medicine, 1-13. https://doi.org/10.3823/1650

Wang, L., Zheng, J., Huang, S., \& Sun, H. (2015). P300 and decision making under risk and ambiguity. Computational Intelligence and Neuroscience, 2015, 1-7. https://doi.org/10.1155/2015/108417

Zurawicki, L. (2010). Neuromarketing: Exploringthe brain of the consumer.Springer Science \& Business Media.

Zito, M., Fici, A., Bilucaglia, M., Ambrogetti, F. S., \& Russo, V. (2021). Assessing the emotional response in social communication: the role of neuromarketing. Frontiers in Psychology, 12, 625570.

https://doi.org/10.3389/fpsyg.2021.625570 